The University of Maine

DigitalCommons@UMaine

3-1-1954

\title{
The Mid-Nineteenth-Century Temperance Movement in New Brunswick and Maine (1954)
}

J. K. Chapman

unknown

Follow this and additional works at: https://digitalcommons.library.umaine.edu/maine_women_acad_all

Part of the Women's History Commons

\section{Repository Citation}

Chapman, J. K., "The Mid-Nineteenth-Century Temperance Movement in New Brunswick and Maine (1954)" (1954). Academic Literature and Research Reports. 10.

https://digitalcommons.library.umaine.edu/maine_women_acad_all/10

This Article is brought to you for free and open access by DigitalCommons@UMaine. It has been accepted for inclusion in Academic Literature and Research Reports by an authorized administrator of

DigitalCommons@UMaine. For more information, please contact um.library.technical.services@maine.edu. 


\section{PROJECT MUSE}

The Mid-Nineteenth-Century Temperance Movement in New

Brunswick and Maine

J. K. Chapman

The Canadian Historical Review, Volume 35, Number 1, March 1954, pp. 43-60 (Article)

Published by University of Toronto Press

$\Rightarrow$ For additional information about this article https://muse.jhu.edu/article/623202/summary 


\section{THE MID-NINETEENTH-CENTURY TEMPERANCE MOVEMENT IN NEW BRUNSWICK AND MAINE}

\section{J. K. Chapman}

$N$

OWHERE did the attempt to introduce temperance into North America during the mid-nineteenth century produce a sharper conflict than in Maine and New Brunswick. ${ }^{1}$ In the late forties and early fifties this region became a focal point of a crusade against "strong drink," which, having begun as a religious movement of moral reform, became a powerful political force seeking to impose its will on the community. New Brunswick had a provincial temperance society in $1830,{ }^{2}$ two years before the founding of a state temperance society in Maine, but it was from Maine that provincial advocates of enforced abstinence drew much of their inspiration and encouragement, as the following pages will show.

Before the late eighteen-twenties there were few in Maine or New Brunswick who were aware of any moral and social implications in heavy drinking. In older New England a reaction to intemperance had begun about the turn of the century, but for a generation it was a spasmodic and unorganized movement among clergymen who found it difficult to save souls whose mortal shells were immersed in alcohol. It found formal expression in the American Temperance Society, founded in Boston in 1826. As laymen became interested in temperance, the movement grew more secular in outlook, and excessive drinking began to be considered in the light of its effects upon society. ${ }^{3}$ These developments, as well as the differences which arose within the movement between "temperance" men and "total abstainers," and between "moral suasionists" and those who desired restrictive legislation, were reflected during the growth of organized temperance agitation in New Brunswick and Maine.

Here, as elsewhere in North America, heavy drinking had long been accepted as an integral feature of everyday life. There were several factors which tended to reinforce the hard-drinking habits

\footnotetext{
1The writer wishes to acknowledge the usefulness of Miss Ruth Nicholson's research in this field. See her unpublished M.A. thesis, "Maine-New Brunswick Relations 1837-1849," University of New Brunswick, 1953.

2James Hannay, History of New Brunswick (Saint John, 1909), I, 447.

3The development of the temperance movement in the United States before 1851 has been fully described by J. A. Krout, The Origins of Prohibition (New York, 1925).
} 
of the people. Maine and New Brunswick were frontier areas whose basic industry was lumbering, ${ }^{4}$ an expanding industry and one which was notorious for its reliance upon rum. Moreover rum was a vital commodity in the trade of the region with the West Indies and was received in exchange for lumber and fish. Import duties on alcoholic beverages provided a significant part, indeed for many years a major part, of government revenues. ${ }^{5}$ Of great importance in New Brunswick was the revenue derived from customs duties which, at least until 1837, provided all but a fraction of the funds at the disposal of the Assembly. There can be small wonder, then, that there was little inclination on the part of business and commercial interests to deplore the existence of a trade so basic to their prosperity, or on the part of assemblymen to interfere with the source of provincial solvency or with their own independence of the authority of the Crown.

Alcohol, in one form or another, occupied an important place in the community. "Spirits, especially rum, was very cheap, and the duty being only thirty cents a gallon, everyone could afford to drink it." $\mathrm{A}$ rum ration was part of the wages paid to workers, for an employer who did not provide rum found it hard to obtain

\footnotetext{
${ }^{4}$ After 1820 greater attention was paid to agriculture but that industry had never been separable from lumbering and even today many small farmers in the less fertile areas combine both occupations.

${ }^{5}$ In 1824 customs duties levied by the New Brunswick legislature provided $£ 30,632$ out of a total revenue of $£ 44,670$. The greater part was derived from spirits, and rum alone produced $£ 17,000$ (see P.R.O., C.O. 193/7). In 1831, duties on rum produced $£ 12,000$ out of a total provincial revenue of $£ 32,939$ ( see P.R.O., C.O. 193/14). Even in 1841, a year of large-scale illicit imports of spirits because of high duties (see Journal, House of Assembly of New Brunswick, 1841, 56, $152), \& 20,000$ was collected on spirits from duties levied under provincial Acts alone and several thousand pounds under authority of Acts of Parliament (see P.R.O., C.O. 193/24).

${ }^{6}$ The amount of rum and other spirits consumed in New Brunswick during the early days of the temperance movement may be roughly estimated through calculations based on the population of the province and the net imports of spirits into the colony. For example, in 1833, with a population of 100,000 (P.R.O., C.O. 193/13), 271,000 gallons of rum and 42,000 gallons of other spirits were legally available for consumption (figures given to the nearest thousand gallons), thus providing for a per capita consumption, respectively, of 2.7 and .42 gallons for the year. Similar annual figures for the late twenties and early thirties may be calculated, the volume of spirits imported and exported being secured from the appropriate New Brunswick "Blue Books," P.R.O., C.O. 193/12, 13, 14, 15, 16. These figures would indicate that if all the adult males drank, say one in seven in those days of large families, then their average annual consumption of legally imported spirits during the period would be about seventeen gallons, mostly of undiluted rum.

7James Hannay, Life and Times of Sir Leonard Tilley (Saint John, 1897), 214. The duty in 1831 was one shilling per gallon under provincial Act and six pence under Act of Parliament (P.R.O., C.O. 193/14).
} 
labourers. At eleven in the morning and four in the afternoon a church bell was rung and all work stopped for the rum dole. ${ }^{8}$ Rum was reported to be the chief article sold in country stores and many shopkeepers kept stocks of liquor to treat customers and induce them to buy other goods. The little town of Calais, Maine, had nine legitimate "rum holes" and liquor was sold in many cellars without benefit of licence. "The use of liquor was considered necessary to happiness, if not to actual existence. . . . Rum was supposed to be an infallible cure for nearly every ill that flesh is heir to, nothing could be done at that time without its use." Every festive occasion called for heavy drinking; the fish run in spring, a barn raising, military parades, a Fourth of July, or a "Glorious Twelfth."

The lumberers were an especially intemperate element in the community. They drank great quantities of undiluted rum, and, after the winter work was done and the spring drive over, they "passed some weeks in idle indulgence, drinking, [and] smoking."10 Since lumbering was the main industry in both Maine and New Brunswick, the habits of the woodsmen exerted a considerable influence upon the rest of the community. Henry Clubb of Maine reported in 1856:

The lumber interest employs many of the bone and muscle (undeveloped morally and intellectually) of society, who are kept in the forest and on the river in a semi-savage state; away from the restraining and refining interests of good society. They are wild men, and like certain animals (upon which they feed, by the way) are fond of swill and will root if not rung. This kind of society has its demands and there are always enough to meet them with the supply. ${ }^{11}$

It is scarcely surprising that the people of Maine and New Brunswick began to connect this widespread consumption of liquor with problems of economic depression and high rates of crime, or that the advocates of temperance expected a great reform in society from the success of their crusade. Neal Dow, a prominent Maine temperance leader, stated, "No person could fail to notice the general poverty of this state, ... and much of the poverty was the direct result of the general distribution of the traffic in liquor."12 "It was the regular thing-rum, slothfulness, poverty and lawless-

\footnotetext{
184.

8Fred M. Dow, “The History of Prohibition in Maine," Americana, XXIII (1930),

9Hannay, Life and Times of Sir Leonard Tilley, 213.

${ }_{10} \mathrm{John}$ MacGregor, British America (Edinburgh, 1832), II, 302.

${ }^{11}$ Henry S. Clubb, The Maine Liquor Law: Its Origin, History, and Results, Including a Life of Hon. Neal Dow (New York, 1856), 211.

${ }^{12}$ Neal Dow, The Reminiscences of Neal Dow (Portland, 1898), 176.
} 
ness." 13 Dow had been director of the Portland alms-house and was much impressed with the connection between drunkenness and poverty. Of 975 persons examined at the Auburn (Maine) State Prison in 1836, 736 were intemperate and 589 were committed for deeds done under the influence of strong drink..$^{14} \mathrm{~A}$ legislative committee on licence laws in Maine reported that poverty, a large number of crimes, and loss of property were caused by drink. ${ }^{15}$ In New Brunswick, drunken election riots, the result of free "booze" handed out by politicians, had become a menace. A Grand Jury reported in 1849:

We fully concur with his Honour [Mr. Justice Parker] in believing intemperate drinking to have been the chief incitement to the commission of most of the offences which we have been called upon to enquire into. And believing also that drunkenness is everywhere the parent of other crimes, we hold it to be the duty of every member of society to assist in devising and carrying out plans for the eradication of this great evil. ${ }^{16}$

The merchants and shipowners of Saint John sent a memorial to British underwriters, shipowners, and shipmasters, pointing out

That the experience we have had in the management of our shipping ... clearly proves to us that the improvement in our Building . . . has not tended more to the safety and character of our Ships than has the introduction of Temperance Principles on board many of them. . . . The adoption of Temperance Principles on board all British and Colonial Ships would tend, frequently very materially to reduce the length of voyage, . . . the character of our Seamen would be improved, and our Mercantile Marine body be sober and well behaved, instead of what they heretofore too much have been, drunken and disorderly. ${ }^{17}$

One of the chief motivations of the temperance movement was thus a practical one: the desire to curb economic loss and crime arising out of drunkenness. But the temperance cause was strengthened, and its appeal broadened, by the spiritual tinge derived from whole-hearted church support, as well as through being linked with other relief and reform movements: anti-slavery in Maine, and immigrant relief in that state and in New Brunswick. There was also an idealistic element in the movement, a desire to remove poverty and vice and to protect the social order. Neal Dow expressed this attitude thus: "We would not prohibit the sale of ardent spirits because it is inconsistent with our religious and moral obligations, ... but because the traffic is inconsistent with our

13 Ibid., 172.

14New-Brunswick Courier (Saint John), March 4, 1837.

${ }^{15}$ Maine Farmer (Augusta), May 2, 1840.

${ }^{16}$ New-Brunswick Courier, Jan. 27, 1849.

17Ibid., March 18, 1843. 
obligations as citizens of the state, and subversive of our social rights and civil institutions." 18 The temperance crusade was a middle-class and respectable movement from the beginning. In time it grew strong enough to secure the attention of the political parties and to warrant legislative support.

Temperance workers in the early period stressed personal abstinence and the idea of "moral suasion" to achieve their ends. The work was promoted, and largely managed, by clergymen. But progress was slow and discouraging and soon many came to feel that temperance could only be achieved through legislation. This was demonstrated in Maine in 1837, when a new Maine Temperance Union was formed, led by General James Appleton and Neal Dow. Conditions of membership were the signing of a pledge of total abstinence, and a stated belief in legal persuasion. The change to the new principle came more slowly in New Brunswick and moral suasion was never completely discredited. Even as late as 1849 the previously mentioned Grand Jury stated: "No good need be expected ... from withholding in every case the license to sell such liquors, as this would be sure to increase the consumption of them. . . . To our pulpits and schools, aided by the examples of parents and guardians must we look, rather than to special enactments, for a diminution of the various sorts of intemperance which now so fully abound."19

The switch in emphasis from personal abstinence to a demand for prohibitive legislation was supported by the churches. A meeting of the Bowdoinham Association of Maine, in 1839, resolved, "That the manufacture and use of all intoxicating drinks be legally suppressed, and these alarming and formidable obstacles in the way of our country's peace and happiness and the success of the Gospel, may be removed forever." 20 But despite the endorsement of the churches the natural result of the change in stress to legal persuasion was that the movement, of necessity, became more secular, and the politician rather than the minister became the leader. Appleton, of the Maine Society, was a candidate for governor of the state and Samuel Leonard Tilley, the head of the movement in New Brunswick, was a rising provincial politician.

In 1840, the Washingtonian Society was formed in Baltimore. ${ }^{21}$ It made its appeal directly to the drunkard, and accomplished spectacular reforms. Many of the techniques used were those of

18N. Dow, Reminiscences, 246.

${ }^{19}$ New-Brunswick Courier, Jan. 27, 1849.

${ }^{20}$ Henry Burrage, History of the Baptists of Maine (Portland, 1904), 295.

21Krout, Origins of Prohibition, 182. 
the religious revival. Washingtonians waged a fierce war against "liquid fire and distilled damnation." The movement was popular and greatly stimulated temperance interest both in Maine and New Brunswick. Huge crowds attended their public meetings. ${ }^{22}$ While the Washingtonian movement died out in about five years, the impetus it had given to temperance in Maine and New Brunswick remained.

By the early forties concrete results of the temperance agitation began to be apparent. In Maine the city of Portland decided in 1842 to grant no further licences for the sale of liquor. Local option laws became frequent throughout the state. Various petitions were printed and circulated pleading with the state legislature for a stringent liquor law. In 1846 one such petition, reputedly bearing forty thousand signatures, was laid before the legislature. The result was the passage in that year of a law prohibiting the sale of liquor for beverage purposes except in amounts greater than 29 gallons. By this means it was hoped to discourage working men from intemperance for, obviously, they could not afford to purchase alcohol in such large quantities. However, enforcement of the law was weak and it remained an ineffectual measure.

Meanwhile temperance activity flourished in New Brunswick. Societies sprang up in Fredericton, Dorchester, Chatham, St. Stephen, and St. Andrews and temperance soirees and teas were very popular. ${ }^{23}$ The movement was well represented in the provincial press, especially by the Telegraph of Saint John. In 1843 an American lecturer, named Ryder, toured the province and at Fredericton nearly five hundred people joined the local temperance society after his meetings. Progress was evidently being made for it was reported that, "Thanks to the healthy tone of morals which has been introduced through the influence of Temperance principles, it is not now reckoned creditable to kill time in the tavern."24 That the movement had also achieved some stability is demonstrated by the fact that societies often organized themselves into joint stock companies, acquired property, built temperance halls, and collected extensive libraries. But it was not until 1847 that interest

${ }^{22}$ One such gathering near Calais was described in the local paper in these terms: "The Washingtonian celebration on Wed. last surpassed everything of the kind ever known in the town before. There were between four and five thousand people at the grove to which they adjourned because the church was not large enough for the women even." Calais Advertiser, July 13, 1843.

${ }^{23}$ Accounts of these foundings and social events may be found in any of the local papers of the period which survive, especially in the New Brunswick Reporter and the Telegraph.

${ }^{24}$ New Brunswick Reporter (Fredericton), Dec., 1843. 
in the temperance crusade in New Brunswick approached that in Maine.

One important aspect of the movement in the province was the part played by the Irish Catholics. In New Brunswick the Irish Abstinence Society was one of the most vigorous groups connected with the cause and its branches were especially active from 1841 to 1845. Many of the immigrants had been influenced by Father Mathew, the great temperance crusader in Ireland, and brought their principles with them. They helped in founding the St. Croix Catholic Temperance Society in Calais, Maine. But in the greater part of Maine the Irish were regarded as the chief enemies of temperance and "Irish" was almost synonymous with "rumseller."

The temperance crusaders had of course to meet the opposition of the liquor interests. The latter could not be expected to enjoy having their businesses attacked as being "accursed and nefarious," their best customers reformed, or most serious, their retail outlets closed. They fought the prohibitionists in every way possible. As the question entered the realm of politics more strife was aroused. Since the movement had the greater success in Maine, it was here that the most bitterness occurred. Wealth was generally on the side of liquor because of its connection with the West Indies trade. Rumsellers were often the most prosperous and influential men in the community. Liquor venders in various towns and cities petitioned that the Act of 1846 be repealed. Violence occurred. Neal Dow was attacked and temperance men had their houses and barns burned, their cattle injured. Dow wrote: "The contest was earnest. In many instances it became bitter. It extended into the churches, disrupted their harmony, emptied not a few of the pews. . . . Almost every organization in which citizens were associated for one purpose or another was affected by it, dividing into 'ramrods,' and 'rummies." "26 The political parties were split and party organization was weakened. People voted, not for the party, but for or against the avowed temperance candidate. For example Calais, in 1847, had a whole slate of temperance nominations for selectmen and had well-organized support for them. ${ }^{27}$

In New Brunswick, the increased strength of the crusade after 1847 came from the Sons of Temperance. This group, which had been organized in New York in 1842 and 1843, spread to Maine in 1844 and the first Sons of Temperance division in British North America was formed in March, 1847, at St. Stephen. It was an off- 
shoot of the Boundary Division which drew its members from Baring, Calais, Eastport, St. Stephen, and Milltown. ${ }^{28}$ By September, eight other divisions had been organized in New Brunswick and the movement spread like wildfire.

The Sons of Temperance was well organized and had a definite structure, and its meetings followed a well-defined ritual. It had, therefore, some of the earmarks and appeal of a secret society. Every member of the family could belong, since there were also Daughters of Temperance and Cadets of Temperance. The organization attracted many by its teas, picnics, and steamer excursions between Calais, Eastport, and Saint John, and up local rivers.

The Sons of Temperance in New Brunswick was very closely allied with the American movement; herein lay its strength and its weakness. The New Brunswick group had the advantage of the backing of a strong American organization with considerable funds. Special speakers could be brought in from the United States. There was a succession of them from 1847 on: Philip S. White, the Most Worthy Patriarch of the Sons of Temperance of the United States, J. G. Gough, J. Miller, and others. These lectures drew large audiences and added many new members to the society. The crossstimulation of ideas was valuable. Sons of Temperance members from Calais and Eastport made a yearly visit to Saint John. In 1849 there was an impressive procession of seventeen hundred, with plumed horses, banners, and bands. These activities increased the enthusiasm of the societies in both Maine and New Brunswick and furthered friendly relations between them.

On the other hand, however, some objections were raised in New Brunswick to the close connection of the provincial Sons of Temperance with the American parent body. It was feared that the Sons of Temperance was a radical, disloyal group. An address was given by James S. Ballentine of the Albion Division, "to endeavour to do away with some unfavourable impressions which rest upon the minds of many warm advocates of the cause." He stated: “. . . one of these unfavourable impressions(if we may so style them) is that we wish to do away with the old order of things; that we wish to depart from the beaten track, and substitute in their stead principles of a Republican character, foreign to the British mind and usages." He emphatically denied this charge and concluded "that nothing exist [s] in this benevolent society that would tend to weaken our love for the British Crown or Constitution." ${ }^{29}$ S. F. Cary 28Ibid., Jan. 28, 1847, March 11, 1847. $\quad{ }^{29}$ Telegraph (Saint John), Feb. $28,1848$. 
of Temperance Cottage, Ohio, the headquarters of the American movement, wrote to Asa Coy, Grand Worthy Patriarch of New Brunswick: "Men of all climes, all parties, all Religions may without compromise of conscience or principle unite in this brotherhood."30

Despite the charges levelled at the Sons of Temperance, it evidently made some progress in New Brunswick-very considerable progress, if we are to credit one provincial journalist, who wrote: "The Temperance Societies in their day effected some good; The Total Abstinence Societies, much more; But the blessings diffused by the orders of the Sons of Temperance are great and incalculable. May they continue to flourish." ${ }^{31}$ The organization indeed was formidable enough to make it worth while for the legislature to propitiate it by a grant of fifty pounds to support the temperance Telegraph. ${ }^{32}$ A grant was also made for the building of a temperance hall in Fredericton on the understanding that other groups could use its facilities. ${ }^{33}$

Meanwhile in Maine, Neal Dow and his cohorts were gaining more supporters and by 1851 had sufficient strength to enact an effective prohibition law. This was the so-called "Maine Law," the first prohibitory liquor law in North America. The new law prevented the manufacture and the sale, except for medicinal and "mechanical" purposes, of any spirituous or intoxicating liquors. ${ }^{34}$ Its enforcement met with considerable success in those areas which were not contiguous to New Hampshire or New Brunswick where the manufacture and sale of liquor were still unrestricted. In the latter districts, like the St. Croix area, liquor could be easily obtained by taking a few minutes' walk from Baring or Calais to the New Brunswick towns. But even on the St. Croix, considering the diffculties facing the enforcement of the law, "much good has been effected."35 The Provincial Patriot of St. Stephen noted in 1853 that it was "a caution" the way in which "the boys have come over to our side for their bitters" and drew the conclusion that "the Maine Liquor Law must be somewhat regarded in Calais." 36 There can be no doubt that, after the passage of the Maine Law, New Bruns-

30New Brunswick Reporter, Feb. 2, 1849.

${ }^{31}$ St. John Morning News, July 3, 1848.

32G. E. Fenety, Political Notes and Observations on New Brunswick (Fredericton, 1867), I, 258.

${ }^{33}$ New Brunswick Reporter, Jan. 5, 1849.

34 Maine Legislative Documents, H.D. 2, 1851.

35 Clubb, Maine Liquor Law, 217, 218.

36Provincial Patriot, June 3, 1853. 
wick enjoyed an increasing popularity with many people from the state of Maine. Considerable quantities of alcohol were conveyed thence to Maine, but the favourite vehicle was the stomach. ${ }^{37}$

The Maine Law of 1851 was amended in 1853, and superseded in 1855 by a still more stringent Act which prohibited the transport of liquor. ${ }^{38}$ The introduction of prohibition in Maine, and the opposition which developed against it, further confused state politics, which had been rendered chaotic enough already by the controversy over the extension of slavery. A New Brunswick paper in September, 1854, quoted the Boston Daily Chronicle as follows: "The election in Maine takes place in a week from Monday next. . . . All parties and factions are so mixed up and shaken together like cats in a bag, that one feels no little curiosity to see which will come out first, when it is opened, or how far any one of them has succeeded in swallowing up one or more of the others." ${ }^{\text {"39 }}$ The Democratic party in Maine had split into pro-slavery and anti-slavery factions and into temperance and anti-temperance forces. In the summer of 1854, the anti-slavery wing and the temperance advocates joined with the Whigs to form the Republican party of Maine, just a month after the founding of the National Republican party at Jackson, Michigan. The allies did not adopt the new name until the following winter, but co-operated in the September election to secure the victory of Anson P. Morrill as Governor on a platform of opposition to the extension of slavery and support for the prohibitory liquor law.

The years between 1849 and 1852 were years of greater friendship and freer intercourse between Maine and New Brunswick than had hitherto prevailed. ${ }^{40}$ The adoption of free trade by Britain had temporarly weakened the links between mother country and province, and the latter had turned towards the United States for aid in her economic extremity, and to co-operation with Maine on the European and North American Railway project. That this period occurred at the same time as the temperance movement achieved success in Maine was coincidental, but the fact that New Brunswick, for the time being, had moved even closer to Maine enabled the

37There is no evidence of the development at this time of such elaborate techniques as that reported by the Eastport Sentinel in 1880 where "among the latest discoveries in the shape of a device for smuggling liquor is a tin bustle, manufactured for an Eastport female for the above purpose. It was filled but not in position when discovered." Quoted in Harold A. Davis, An International Community on the St. Croix, 1604-1930 (Orono, 1950), 301.

38Clubb, Maine Liquor Law, 78. $\quad 39$ New Brunswick Reporter, Sept. 6, 1854.

40The great railway convention at Portland, Maine, in 1851 which was attended by a large group of New Brunswickers was a mark of this period of co-operation. 
temperance movement to exert an even greater influence upon the province than it had in the past. Temperance advocates in New Brunswick were so encouraged by the passage of the Maine Law, and had become so influential in the province, that in 1852 the legislature was persuaded to pass "An Act to Prevent the Traffic in Intoxicating Liquors."

This Act was very similar to the Maine Law and forbade the manufacture within New Brunswick of any alcoholic or intoxicating liquors except for religious, medicinal, or chemical purposes. Beer, ale, porter, and cider were excepted. The only persons authorized to sell liquor were agents appointed by the sessions or by a city or town corporation. The new Act was to come into operation on June 1, 1853. It was, however, never obeyed, for its enforcement clause was defective. In the session of 1854 a new bill was brought forward, lengthily debated, and amended by its opponents until its advocates refused to support it. It was finally rejected.

In the meantime Samuel Leonard Tilley, member of the legislature from Saint John, had emerged as the leading proponent of temperance in the province, and in June, 1854, he was unanimously chosen Most Worthy Patriarch of the Sons of Temperance in North America-a mark perhaps not only of his capacity for leadership but also of the importance with which the Sons of Temperance throughout North America regarded the movement in New Brunswick. In the same month a "grand Temperance Demonstration," attended by representatives from Canada and the United States, took place in Saint John. In the summer of 1854 a provincial election occurred, resulting in the accession to power of the Liberal party, led by Tilley and Charles Fisher. In the session of 1855 Tilley put forward, as a private member, a new prohibitory liquor bill patterned after the Maine Law. ${ }^{42}$ The bill passed by the narrow margin of 21 to 18, despite the opposition of the Lieutenant-Governor, Manners-Sutton, and several members of the Executive Council of which Tilley, as Provincial Secretary, was the leading member.

Manners-Sutton, in spite of his personal disapproval, gave his assent to the bill and it became law, destined to go into effect at the beginning of 1856. In explanation the Lieutenant Governor wrote: "Had the three members of my Council, who opposed the Liquor bill in every stage of its progress through the House of Assembly ... declined to advise me to assent to the measure ... I should have

41 Journal, House of Assembly of New Brunswick, 1852.

42P.R.O., C.O. 188/124, Observations of the Attorney General of New Brunswick re Acts passed in $\mathbf{1 8 5 5}$. 
acted on their opinions and not on those of the majority of the Council." ${ }^{.43}$ In the same despatch he remarked that the difficulties facing the opponents of the liquor bill were increased by the fact that similar bills were, at the same time, under discussion both in Canada and Nova Scotia. ${ }^{44}$

The Lieutenant-Governor and the opponents of prohibition had lost the first round but they were not to lose the second. By the spring of 1856, only a few months after the new liquor law had come into operation, Manners-Sutton had reached the conclusion that it must be repealed. The province was faced with a falling revenue. There had been a deficit in 1855, and the loss in 1856 of some $£ 25,000^{45}$ in import duties on spirits and wines would be a serious blow to financial stability. He could argue also that the liquor law had been resisted successfully ever since it had come into operation and that a law which had not been and could not be enforced should be repealed, or else "habits of lawlessness" would be engendered among the people and "the legislature as well as the Law in general would be brought into contempt." 46 Accordingly, in May, 1856, he called upon the Executive Council to consider repealing the liquor law and when the Council refused he asked it to advise a dissolution. This, the Council also refused to do, whereupon Manners-Sutton ordered a writ to be prepared calling for new elections. The Council resigned but the Lieutenant-Governor was able to secure advisers who would assume responsibility for his action. ${ }^{47}$

Manners-Sutton was immediately assailed by the Liberals and prohibitionists as a tyrant and the betrayer of the principles of responsible government. The Tories and liquor interests praised him for his action. ${ }^{48}$ The New Brunswick Courier, while opposed to the prohibitory law, was pro-Liberal and it castigated the LieutenantGovernor for his dissolution of the legislature. Throughout May and June it printed many editorials and letters charging that, although the Lieutenant-Governor undoubtedly had a legal right to order

43P.R.O., C.O. 188/125, Manners-Sutton to Russell, July 4, 1855.

44Ibid.

${ }^{45}$ In 1856, \&23,831 were raised from import duties on wines and spirits (P.R.O., C.O. 193/39). The total revenue that year was nearly $£ 120,000$. Presumably had duties on spirits and wines been levied throughout the year instead of only seven months, the amount collected would have been somewhat higher.

46P.R.O., C.O. 188/127, Manners-Sutton's Memorandum for the Executive Council, enclosure IA in Manners-Sutton to Labouchere, May 31, 1856.

47P.R.O., C.O. 188/127, Manners-Sutton to Labouchere, May 31, 1856, and enclosed memoranda to and from Executive Council.

48Hannay, History of New Brunswick, II, 181. 
new elections, the exercise of this right was a high-handed use of the prerogative which would raise a storm even in England. ${ }^{49}$ According to the editor, such a course was unprecedented in British North America since the establishment of responsible government. ${ }^{50}$ The wrath of an aroused electorate would surely be visited upon Manners-Sutton and his new Government. ${ }^{51}$ The New Brunswick Reporter opposed the dissolution also on the ground of the arbitrary exercise of power. $^{52}$ The Miramichi Gleaner thought MannersSutton's action both arbitrary and premature. ${ }^{53}$ The St. John Freeman and the New Brunswicker supported the Lieutenant-Governor, the former on legal grounds, the latter because he was submitting the question of the liquor law to the people rather than to a legislature whch no longer commanded the support of the people. ${ }^{54}$

Neither Manners-Sutton nor the officials in the Colonial Office had any doubts respecting the constitutionality of the dissolution. The position was simple: If the Lieutenant-Governor declined to accept the advice of his Executive Council, the Council had no course but to resign and allow him to seek new advisers. ${ }^{55}$ The only question which arose in the Colonial Office was whether MannersSutton's procedure had been expedient. Sir Herman Merivale, the permanent undersecretary of state, thought the course of action should be disapproved, for Manners-Sutton had run a great risk of destroying his usefulness for the sake of "getting rid a little sooner of advisers whom he disliked." "56 However, Labouchere, the secretary of state for the colonies, advised waiting for the results of the elections in New Brunswick before replying to Manners-Sutton's despatch. ${ }^{57}$

Although Manners-Sutton undoubtedly disliked his advisers ${ }^{58}$ as

49New-Brunswick Courier, May 24, 1856, June 7, 1856.

solbid., May 17, 1856. The editor noted that Sir Edmund Head had once used the prerogative in appointing judges in New Brunswick but he had had his Council with him. Even then, the Assembly had nearly passed a vote of "no confidence" which, had it been carried "would have dissolved the Government and Sir E. Head never would have been Governor-General of Canada."

51 Ibid., May 24, 1856.

52Miramichi Gleaner, May 31, 1856. This paper printed a column of editorial opinions held by its contemporaries.

53Ibid.

54Ibid.

55P.R.O., C.O. 188/127, Manners-Sutton to Merivale (Private), June 13, 1856.

56P.R.O., C.O. 188/127, Merivale's minute June 24, 1856 on Manners-Sutton to Labouchere, May 31, 1856.

57P.R.O., C.O. 188/127, Labouchere's minute June 25, 1856 on Manners-Sutton to Labouchere, May 31, 1856.

${ }^{58}$ Hannay (History of New Brunswick, II, 180) remarks on this dislike and Manners-Sutton himself appears to have confirmed it in his private letter to Merivale (P.R.O., C.O. 188/127) June 13, 1856, when he wrote that his difficulties had been 
Merivale indicated, the working of the prohibitory law provided a sufficient reason, without adding a personal motive, for his desire to rid himself of a Council which refused to consider its repeal. The loss to the revenue was perhaps enough by itself. But while the law had effectively prevented the raising of customs it had not actually prevented the sale or consumption of liquor. It is true that the measure had been in operation only a few months and so, perhaps, had not been given a fair trial; but if such experience of its operation as had been obtained was any guide to its future course, then the law had best be repealed. Liquor continued to be sold with impunity in every part of New Brunswick. Legal proceedings had been taken in some instances, but these were "exceptional cases, and the punishment of a few individuals for acts which multitudes may and do commit without punishment and without question only aggravates the evil for when justice ceases to be evenhanded, it ceases to be justice. ${ }^{59}$ The few convictions for contraventions of the Act which had been obtained had been against "persons of the very humblest classes whilst ... [the law] was openly disregarded and set at defiance by the Hotel Keepers, Restaurants, Dealers, etc., and persons in better circumstances." lawyers to defend them and were able to continue their sales of liquor. ${ }^{61}$

The provincial elections, held in the early summer, were bitterly contested. Every attempt was made by the Liberals to make the constitutional question the main issue, and friends of the dismissed Executive accused their opponents of desiring to repeal the secret ballot Act which, though passed, had yet to come into operation. ${ }^{62}$ Judging by the results of the elections these issues counted for little against the desire to get rid of the unpopular and unsuccessful liquor law. Tilley and James Brown, the surveyor-general in the old Council, the sponsors of the prohibitory law, were defeated. The

of eighteen months' duration-the length of the Tilley-Fisher Council's term of office. The editor of the New-Brunswick Courier noted on May 31, 1856, that it was generally understood that Manners-Sutton "had no sympathy or liking for his constitutional advisers."

59P.R.O., C.O. 188/127, Manners-Sutton's Memorandum for the Executive Council, enclosure IA in Manners-Sutton to Labouchere May 31, 1856; vide also Hannay, History of New Brunswick, II, 177.

60P.R.O., C.O. 188/127, Observations of John H. Gray (the new Attorney-General of New Brunswick) on the "Act to repeal the Act to prevent the Importation, Manufacture and Traffic in intoxicating Liquors and to regulate the sale thereof," Aug., 1856.

61Hannay, History of New Brunswick, II, 177. Hannay was a Liberal and a defender of Tilley. His testimony on this point is undoubtedly correct.

62New-Brunswick Courier, May 3, 1856, May 11, 1856, May 24, 1856. 
new legislature contained but two friends of prohibition. ${ }^{63}$ The prohibitory law was repealed in July, 1856, and the licensing laws of 1854 were re-established. A resolution was also passed endorsing the Lieutenant-Governor's conduct, but whereas the repeal of the liquor law had been carried with only two negative votes, the resolution passed by the comparatively narrow margin of 23 to 16 .

This whole political controversy over temperance in New Brunswick raises an interesting but difficult question: How was it that the prohibitory law could be passed in one year, albeit by a majority of three, and yet be signally defeated by the electors the following year, especially when its defenders were given an added issue-the exercise of the prerogative-upon which to attack their opponents? The answer may perhaps lie in the fact that the prohibitory law of 1855 was not a party measure. It had passed by a majority of only three in a House in which the Liberals had a majority of at least ten or twelve. Why had it passed? "Its enactment was necessary to satisfy its friends." ${ }^{\text {" }}$ Liberals were confident that they themselves would repeal the law, but had it been repealed during the early session of 1856 "there would have been the complaint of unfairness and renewed agitation." ${ }^{2}$ Before the dissolution, the New-Brunswick Courier, a Liberal journal, called upon the friends of the law to "assent to the inevitable necessity of repealing it at the next session."66 In other words, a sufficient number of Liberals had given in, at least temporarily, to a pressure group headed by the Liberal leader, Tilley. The Liberal party and even the Executive Council was split on the subject ${ }^{67}$ although the Council closed its ranks in the face of Manners-Sutton's attempt to force it to repeal the Act. Other factors should be taken into account. According to Hannay, it was generally held that many in the Assembly who voted for prohibition thought they might make political capital by so doing and relied upon the Legislative Council to throw out the bill. ${ }^{68}$ Undoubtedly there were those who over-estimated popular support

${ }^{63}$ As nearly as can be judged the new house was composed of 21 Tories, 2 prohibition Liberals, 14 or 15 anti-prohibition Liberals, and 3 or 4 independents or anti-Tories who were at the same time anti-prohibitionists.

This judgment is based upon the number of votes cast against repeal of the liquor law, the fact that in 1857 the Tories could only carry on business by the casting vote of the Speaker in a House of 41 members, and the vote in support of the resolution endorsing the Governor's conduct in regard to calling an election.

${ }_{64}$ New-Brunswick Courier, May 17, 1856.

65 Ibid.

68Ibid.

67P.R.O., C.O. 188/125, Manners-Sutton to Russell, July 4, 1855.

68Hannay, History of New Brunswick, II, 175, 176. 
for restrictive legislation and gave the bill their assent as a matter of expediency or because they thought they were following the will of the people. Then there were those who allowed their belief in prohibition to overcome their political sagacity.

Once New Brunswick's prohibitory Act had come into operation and had begun to challenge existing interests ${ }^{69}$ and to interfere with long-established habits, resistance to it had strengthened. The failure of attempts to enforce the Act must surely have fostered doubts respecting the efficacy of legislative action among all but the most hardened of prohibitionists, and strengthened the convictions of those who had continued to believe in "moral suasion" as the one answer to intemperance. But what must have weakened the prohibitionists most in their fight to preserve the Act was the fact that no political party was committed to their philosophy.

In Maine, the presence of a political party founded on the twin principles of prohibition and opposition to the extension of slavery perhaps explains sufficiently why the advocates of enforced temperance were able to beat down the attackers of the Maine Law and why it was even found possible to strengthen that measure. But there were other reasons why the prohibitionists were more successful in that state than in New Brunswick. The Lieutenant-Governor of the province was possessed of greater independence and power than the Governor of Maine and the former had chosen to oppose the liquor law. Maine, moreover, had municipal institutions. Local options were common in the state before 1851, and prohibition could pass from local victory to local victory, meanwhile consolidating its gains. For this reason the prohibitory law in Maine was probably a lesser shock to habits, business, and revenue than in New Brunswick, which, with the two exceptions of the cities of Saint John and Fredericton, had no local self-governing institutions until after 1851. Another factor, of uncertain weight, in this comparison of the relative success of prohibition in Maine and New Brunswick was the predominance of puritanism in the churches in Maine, while the Anglican and Roman Catholic orthodoxies still provided in mid-century half the clergymen in the province. ${ }^{70}$

New Brunswick had rejected prohibition. When in 1857 the Liberals had resumed their party allegiance and another election had returned the Tilley-Fisher party to power, the politically illadvised attempt at achieving temperance by legislation was not repeated. But had New Brunswick rejected temperance? Examina-

69There were about 200 taverns in Saint John and its suburb Portland at this time. 70P.R.O., C.O. 193/34. 
tion of figures for the net imports of rum and other spirits between 1830 and 1856, the period of the temperance movement, shows that the importation of spirits other than rum remained steady at just under half a gallon per capita, but that the importation of rum declined steadily between 1830 and 1840 from over two and a half gallons to just under one, and during the forties and fifties to slightly under half a gallon. Was this a victory for the temperance movement? Unfortunately, we cannot so interpret it. ${ }^{71}$ The decline in rum imports is paralleled by a notable increase in those of molasses, the great drop in rum imports and increase in molasses both occurring about 1843. There are strong reasons for believing that a considerable portion of the molasses imported was being converted by provincial distilleries into rum. The provincial excise tax of one shilling and six pence on rum manufactured locally, imposed in $1829,{ }^{72}$ was removed in $1842,{ }^{73}$ and molasses was made duty-free in $1843,{ }^{74}$ measures that were likely designed, on the one hand, to curb the smuggling of spirits prevalent in the early forties ${ }^{75}$ and, on the other, to promote local industry. Accordingly, in spite of the fact that the imports per capita of rum in the fifties were only very slightly greater than in the preceding decade, it may well be true that New Brunswick's consumption of rum in the fifties exceeded that of the thirties.

Furthermore, had there been a marked decrease in rum drinking in the fifties it must surely have been noted by contemporary observers. Rather than rejoicing, however, there was a demand for prohibitive legislation which would seem to be indicative of an increase, or at least no diminution, in rum consumption. There seems also to be no reason why New Brunswickers should have turned away from drinking rum and yet maintained their consumption of other spirits unless the new immigrants did not take to it. It is perhaps possible to argue that the decline in rum imports per capita in the forties indicates some success by temperance workers. More likely, however, it reflects the almost continuous economic depression of the decade, ${ }^{76}$ and the depressed state of the West Indies, and of New Brunswick's West Indian trade, following the emancipation of the slaves. If this is true, and if it is also true

\footnotetext{
${ }^{71}$ Figures for the net imports of spirits on a per capita basis may be calculated in the same way as before from New Brunswick "Blue Books." See footnote 6.

72P.R.O., C.O. 193/12.

73P.R.O., C.O. 193/25.

74P.R.O., C.O. 193/26.

75 Journal, House of Assembly of New Brunswick, 1841, 55.

${ }^{76}$ The years 1842 and 1843 were especially bad.
} 
that with the prosperity of the early fifties a part of the greatly increased supplies of molasses was converted into rum, the attempt to reduce drinking by moral suasion was a failure. ${ }^{77}$

The direct results of the temperance movement in New Brunswick were perhaps not very great, nor were the aims of its advocates realized. But often the indirect consequences of a crusade are of greater importance than the direct. The temperance movement aroused a political controversy in the province which had two interesting by-products. First, the assumption by the cabinet of the initiative in financial matters was postponed for several years. ${ }^{78}$ Second, the influence and position of the Lieutenant-Governor were reduced to the point where the practice of responsible government was brought into line with its most extreme theory, because the dismissed ministers were so incensed at Manners-Sutton's treatment of them that when they returned to power in 1857 they "sat upon him."79 The temperance movement had other more positive indirect results. It created a greater awareness than had hitherto existed that intemperance was a social evil, and it perhaps increased public order and improved the moral tone of the community. More important, however, was the fact that the temperance crusade, though closely connected with that of Maine, was the first mass movement in the history of New Brunswick. By cutting across class, religious, and national barriers it succeeded, in part at least, in creating a greater sense of community at a time when, with large immigrations of peoples with diverse backgrounds, such a development was most desirable.

77The only point which might contradict this judgment would be that large quantities of rum were exported illegally to Maine after the passage of the "Maine Law" and before the passage in 1855 in that state of a law to prevent the transportation of liquor. I have, however, found no evidence to support this.

$78 \mathrm{~A}$ resolution to give the cabinet the initiative had been introduced and passed in 1855 but the dissolutions and elections which followed prevented its becoming effective. It was again passed in 1858 and the practice of "log-rolling" was curtailed although it did not entirely cease.

${ }^{79}$ Stanmore Papers, Arthur Gordon to Sir Edmund Head, Feb. 18, 1865. (Unpublished private papers in the possession of Lord Stanmore.) Gordon, MannersSutton's successor, considered that the "habit of treating the Governor with contempt has become a custom which has outlived the duration of Manners-Sutton's term and is now become a matter of course. [The Council] . . . look on the Governor simply as their clerk." 